\author{
Б I О X I М I Я Т А Ф I 3 І О Л О Г І Я
}

УДК 591.1:637.1

doi: $10.36359 /$ scivp.2019-20-2.01

\title{
ФІЗІОЛОГО-ФУНКЦІОНАЛЬНА ХАРАКТЕРИСТИКА ОРГАНІЗМУ ВІДГОДІВЕЛЬНИХ БУГАЙЦІВ ЗА ВПЛИВУ ТЕХНОГЕННОГО НАВАНТАЖЕННЯ
}

\author{
В. О. Величко, д-р вет. наук
}

Державний науково-дослідний контрольний інститут ветеринарних препаратів та кормових добавок вул. Донецька, 11, м. Львів, 79019, Україна

Однією з актуальних проблем для тваринництва, зокрема у зонах техногенного забруднення, є розробка науково-практичних основ його ведення. Техногенне навантаження на довкілля і забруднення сільськогосподарських угідь різними ксенобіотиками проявляється імунодефіцитним станом організму тварин, а також може спричиняти мутагенну, тератогенну, навіть ембріотоксичну дію. До основних причин, які суттєво впливають на функиіональний стан організму, здоров'я тварин, відповідно і людей вважають екологічний стан середовища. Особливо гострою ия проблема відчувається в районах, де не контролюються промислові викиди, безсистемно вносяться мінеральні добрива, гербіцииди, пестиииди, засоби стимулювання рослин. Дослідженнями підтверджено, що в таких районах підвишується $i$ вміст важких металів у трунті, водi, відповідно $i$ кормах, які використовуються у тваринництві, щзо знижує біологічну і поживну їх иінність та сприяє накопиченню в організмі токсичних сполук. Тому заслуговує на увагу необхідність вдосконалення, у зонах техногенного навантаження, сільськогосподарського виробництва в иілому, та і системи ведення галузі тваринництва та годівлі тварин зокрема. Виправданим напрямком в иій роботі є проведення моніторингу ксенобіотиків, зокрема важких металів у трофічному ланцюгу: трунт-рослина-корм-тварина-людина.

Важливість одержання саме таких даних викликана ще й тим, що зі зміною інтенсивності прочесів метаболізму в організмі продуктивних тварин у зонах техногенного навантаження можливо иіленаправлено корегувати різними біологічно активними добавками прочеси перетворення компонентів корму $i$ трансформації їх у продукиію, швидкість $i$ напрямок перебігу ферментативних реакцій, $і$, таким чином, нормалізувати окремі ланки обміну речовин, що, відповідно сприятиме підвищенню продуктивних якостей тварин та одержання якісної і безпечної продукиії. Питання наслідків техногенного навантаження на фізіолого-функціональний стан організму тварин потребує розширення відповідних досліджень $i$ відпраџювання заходів як збереження екологічної рівноваги середовища, так $i$ збереження благополуччя тваринництва.

Ключові слова: ТЕХНОГЕННЕ НАВАНТАЖЕННЯ, КСЕНОБІОТИКИ, ВАЖКІ МЕТАЛИ, МЕТАБОЛІЗМ, ЕКОЛОГІЧНА РІВНОВАГА, БЛАГОПОЛУЧЧЯ ТВАРИННИЦТВА.

За оцінками багатьох вітчизняних і зарубіжних вчених рівень продуктивності тварин 
знаходиться в прямій залежності від інтенсивності метаболізму в їх організмі, тоді як підвищення вмісту ксенобіотиків, зокрема важких металів, позначається на порушеннях фізіології живлення та обміну речовин організму. Техногенні продукти впливають пригнічуюче на швидкість ферментативних процесів або повністю їх блокують. Тривалий вплив на організм техногенних продуктів негативно впливає і на здатність відтворення, збереження і продуктивність тварин. Здатність до нагромадження токсичних елементів організмами визначається не лише екологічним станом середовища, але й їх біологічною природою та біогеохімічним ланцюгом, через який здійснюється зв'язок організму i середовища (грунт-рослина-тварина-людина). В свою чергу, інтенсивне техногенне забруднення зумовлює негативний вплив і на саму агроекосистему та може проявляти пряму і віддалену дію на організм тварин і людей. Мають місце повідомлення вчених і практиків про те, що токсичні елементи зумовлюють виникнення захворювань, які призводять навіть до зміни функції окремих органів та систем, їх фізіолого-біохімічного статусу, клінічного стану організму, що проявляється погіршенням здоров'я тварин, та показників їх продуктивності.

Матеріали і методи. Дослідження проводили в господарствах, які знаходились в зоні техногенних викидів Миколаївського гірничо-цементного комбінату (господарство імені I. Франка), та умовно екологічно чистій зоні Львівщини (господарство «Карпати», Стрийського району) на бугайцях чорно-рябої породи. Підбирали тварин-аналогів відповідної породи, живої маси, фізіологічного і клінічного стану. Отримані результати обробляли статистично. Умови утримання тварин і годівля були ідентичні і здійснювалися згідно 3 існуючими нормами.

Результати й обговорення. Проведені дослідження показали, що вміст основних поживних речовин в однакових кормах з господарств різних екологічних зон суттєво не відрізнявся, тоді як суттєві різниці виявлено за мікроелементним складом та вмістом важких металів у кормах, що згодовувались бугайцям. Зокрема, в господарстві імені I. Франка вміст Свинцю у більшості кормів, крім силосу, переважав в 1,5-3 рази, а для меляси - у 8 разів, порівняно до кормів з умовно чистої екологічної зони. Дані досліджень наведені в таблиці 1.

Табличя 1

Вміст мікроелементів у кормах і воді господарства із зони інтенсивного техногенного навантаження (мг/кг сухої речовини корму, мг/л у воді)

\begin{tabular}{|c|c|c|c|c|c|c|}
\hline \multirow{2}{*}{$\begin{array}{l}\text { Хімічні } \\
\text { елементи }\end{array}$} & \multicolumn{6}{|c|}{ Корми раціону, вода } \\
\hline & Силос з різнотрав'я & Солома озима & Комбікорм & Шрот & Меляса & Вода \\
\hline \multicolumn{7}{|c|}{ Господарство імені І. Франка Миколаївського району } \\
\hline $\mathrm{Pb}$ & 1,50 & 3,90 & 2,13 & 2,02 & 6,06 & 0,0017 \\
\hline $\mathrm{Zn}$ & 18,75 & 7,80 & 42,60 & 44,10 & 10,10 & 0,0018 \\
\hline $\mathrm{Mn}$ & 37,50 & 23,40 & 142,00 & 15,12 & 8,08 & 3,57 \\
\hline $\mathrm{Cu}$ & 4,50 & 3,90 & 8,52 & 10,00 & 4,40 & 0,027 \\
\hline Mo & 0,21 & 0,31 & 0,28 & 0,53 & 0,25 & 0,012 \\
\hline $\mathrm{Co}$ & 0,19 & 0,16 & 0,85 & 0,50 & 0,35 & 0,0036 \\
\hline $\mathrm{Cr}$ & 4,50 & 3,12 & 4,26 & 2,27 & 0,10 & 0,018 \\
\hline $\mathrm{Ni}$ & 3,75 & 0,94 & 2,84 & 3,78 & 1,82 & 0,0045 \\
\hline $\mathrm{Sn}$ & 1,50 & 2,73 & 0,28 & 3,15 & 10,10 & 0,0036 \\
\hline $\mathrm{Fe}$ & 756,8 & 621,0 & 57,6 & 79,8 & 1125,0 & 0,31 \\
\hline $\mathrm{Sr}$ & 30,00 & 39,00 & 8,52 & 6,30 & 5,05 & 16,07 \\
\hline $\mathrm{Zr}$ & 4,50 & 5,46 & 7,10 & 3,78 & 1,52 & 0,018 \\
\hline $\mathrm{Cd}$ & 0,075 & 0,080 & - & 0,150 & 0,100 & 0,018 \\
\hline
\end{tabular}

Очевидно, техногенне забруднення навколишнього середовища призводить до нагромадження важких металів у грунтах і підвищеного надходження деяких мікроелементів у рослини, грунтові та підземні води. Зокрема відомо, що збільшення вмісту Хрому в сільськогосподарських культурах може бути викликане за рахунок виділення його в атмосферу 
i розсіювання на значній території із пилом цементу. Для порівняння наводимо дані iз порівняно чистої екологічної зони (табл. 2).

Характерно, що у кормах із промислово-приміської зони (г-во імені І. Франка) виявлено підвищений вміст таких хімічних елементів, як Хрому, Феруму, Кобальту. Вода у цьому господарстві містила 1786 мг/л розчинних речовин проти 392 мг/л у такому ж 3 передгірної зони. Вміст у воді основних мікроелементів (Плюмбуму, Цинку, Купруму, Нікелю, Феруму й інших), за виключенням Барію та нітратів, у цій зоні у 3-6 разів перевищував їх рівень у воді 3 господарства "Карпати" і за рівнем окремих з них (Mn, Sr) не відповідала ветеринарногігієнічним вимогам.

Таблиия 2

Вміст мікроелементів у кормах і воді господарства з умовно чистої екологічної зони (мг/кг сухої речовини, мг/л води)

\begin{tabular}{|c|c|c|c|c|c|c|}
\hline \multirow{2}{*}{$\begin{array}{c}\text { Хімічні } \\
\text { елементи }\end{array}$} & \multicolumn{5}{|c|}{ Корми раціону, вода } \\
\cline { 2 - 7 } & Силос з різнотрав'я & Солома озима & Комбікорм & Шрот & \multicolumn{4}{c|}{ Меляса } & Вода \\
\hline \multicolumn{2}{|c|}{ Господарство «Карпати» Стрийського району } & 0,11 & 0,75 & 0,0004 \\
\hline $\mathrm{Pb}$ & 4,32 & 1,36 & 1,60 & 57,0 & 9,00 & 0,0004 \\
\hline $\mathrm{Zn}$ & 32,40 & 13,84 & 96,40 & 91,20 & 4,50 & 0,20 \\
\hline $\mathrm{Mn}$ & 32,40 & 27,60 & 5,12 & 11,40 & 0,75 & 0,008 \\
\hline $\mathrm{Cu}$ & 7,56 & 3,45 & 0,51 & 0,34 & 0,22 & 0,002 \\
\hline $\mathrm{Mo}$ & 0,34 & 0,31 & 0,13 & 0,28 & 0,30 & 0,004 \\
\hline $\mathrm{Co}$ & 0,22 & 0,34 & 0,64 & 0,57 & 0,07 & 0,004 \\
\hline $\mathrm{Cr}$ & 1,08 & 0,34 & 3,84 & 4,54 & 1,50 & 0,0008 \\
\hline $\mathrm{Ni}$ & 2,16 & 2,76 & 1,92 & 1,14 & 0,22 & 0,0008 \\
\hline $\mathrm{Sn}$ & 2,48 & 1,72 & 57,60 & 79,80 & 1125,00 & 0,31 \\
\hline $\mathrm{Fe}$ & 756,80 & 621,00 & 16,00 & 5,70 & 3,37 & 2,35 \\
\hline $\mathrm{Sr}$ & 43,20 & 41,40 & 0,96 & 1,37 & 1,12 & 0,005 \\
\hline $\mathrm{Zr}$ & 2,16 & 5,52 & 0,064 & 0,11 & 0,075 & - \\
\hline $\mathrm{Cd}$ & - & 0,07 & &
\end{tabular}

Проведені дослідження на бугайцях, які утримувались в умовах інтенсивного техногенного навантаження в господарстві імені I. Франка, Миколаївського району, за умов інтенсивного техногенного навантаження викидами Миколаївського цементного i Роздольського гірничо-сірчаного комбінатів, вказують на значний вплив цих виробництв на клінічний, фізіологічний і відповідно функціональний стан тварин, фізіолого-біохімічнні процеси в їх організмі, порівняно із тваринами, які вирощувались в екологічно чистій зоні передгір'я Карпат в господарстві «Карпати», Стрийського району.

За даними досліджень утримання бугайців на відгодівлі у екологічно забрудненій зоні призводило до зниження інтенсивності кон'югації фенолів у вмісті рубця. У дослідних тварин виявлено вищу концентрацію вільних фенолів у рідині рубця, а також підвищений відсотковий вміст їх у загальній сумі (13,1 проти 6,2 \% у контролі), на 19 \% відзначалося зростання загальних фенолів, порівняно до контролю.

Аналіз даних продуктивності дослідних тварин свідчив, що середньодобові прирости маси тіла були вищими у бугайців з господарства, сільгоспугіддя якого знаходилися в умовно екологічно чистій зоні. В той же час, затрати кормів на кілограм приросту переважали на 10 \% у тварин, які утримувалися в зоні техногенного навантаження.

Одержані експериментальні дані свідчать і про те, що у бугайців 3 техногенно забрудненої зони дещо інтенсифікувався обмін жирів і сповільнювався обмін білків. При забої дослідних тварин у 12-місячному віці у них виявлено вірогідно більший вміст внутрішнього жиру (2,19 проти 1,63 кг у контролі). Також у бугайців, які утримувалися у зоні інтенсивного техногенного навантаження встановлено нижче засвоєння Кальцію, Магнію, Феруму, Мангану, Кобальту, Молібдену, Нікелю, порівняно з контролем, та зворотну залежність до засвоєння Стронцію, Хрому і Кадмію. Різне співвідношення між вмістом макроелементів у кормах і воді 
впливало на інтенсивність засвоєння поживних речовин, у т. ч. і мікроелементів.

Однак, була відзначена тенденція до більшої кількості інфузорій у рубцевій рідині бугайців, які утримувалися в умовах техногенної зони, що може свідчити про функціонування певних адаптивних механізмів в організмі бугайців. Отримані нами дані свідчать і про те, що організм молодняку ВРХ здатний пристосовуватися до певних екологічних умов, у яких перебуває, за рахунок інтенсифікації процесів обміну речовин 3 вираженим проявом адаптаційних можливостей на вищому метаболічному рівні.

У віці 18 місяців (аналогічно до 12-місячного періоду) також є нижчим загальний вміст НЕЖК як насичених (42,7 проти 50,4 мг\% у контролі), так і ненасичених (6,0 проти 9,1 мг\% у контролі) у рідині рубця бугайців зони техногенного навантаження. В цьому ж віці, після переміщення бугайців 3 екологічних умов зони техногенного забруднення (с. Берездівці, Миколаївського району) в умови екологічно чистої зони (с. Нижня Стинава, Стрийського району) в рідині рубця не змінювався загальний вміст насичених (64,1 проти 65,8 мг\%) i ненасичених (21,3 проти 20,5 мг\%), жирних кислот загальних ліпідів.

Відповідну різницю між тваринами контрольної і дослідної групи встановлено і за морфофункціональними показниками печінки, зокрема за величиною середнього діаметру клітинних ядер цього органу $(\mathrm{p}<0,05)$ та за їх об'ємом, що, безперечно, мають відповідне значення щодо оцінки клінічного і фізіологічного стану організму бугайців (табл. 3). Проведені гістологічні і морфометричні дослідження свідчать про підвищення функціональних можливостей клітинних та ядерних структур паренхіматозних клітин печінки бугайців, які утримувалися у зоні техногенного забруднення.

Таблиия 3

Морфофункціональний стан тканин печінки бугайців 12-місячного віку, вирощених за умов техногенного навантаження, $(\mathrm{M} \pm \mathrm{m}, \mathrm{n}=4)$

\begin{tabular}{|c|c|c|c|c|}
\hline Показники & Групи тварин & Клітинний апарат & Ядерний апарат & Дистрофічні ураження \\
\hline \multirow{2}{*}{$\begin{array}{c}\text { Величина середнього } \\
\text { діаметра клітин, мкм }\end{array}$} & $\mathrm{K}$ & $14,96 \pm 0,07$ & $7,37 \pm 0,07$ & $94,39 \pm 7,11$ \\
\hline \multirow{2}{*}{ Площа клітини, мкм } & Д & $17,02 \pm 2,62$ & $8,13 \pm 0,26^{*}$ & $129,58 \pm 3,59 *$ \\
\cline { 2 - 5 } & $\mathrm{K}$ & $217,58 \pm 2,62$ & $54,25 \pm 0,98$ & $8529,88 \pm 1,08$ \\
\hline \multirow{2}{*}{ Об'єм клітини, мкм } & Д & $280,05 \pm 32,91$ & $66,07 \pm 4,23^{*}$ & $14754,84 \pm 1,16^{*}$ \\
\cline { 2 - 5 } & $\mathrm{K}$ & $1409,49 \pm 44,76$ & $201,79 \pm 4,85$ & $331664,63 \pm 59,91$ \\
\hline
\end{tabular}

Аналізуючи продуктивність дослідних бугайців, слід відзначити певні різниці за середньодобовими приростами. У бугайців, які утримувалися в зоні техногенного навантаження, середньодобові прирости були найменшими.

Згодовування кормів, вирощених у зоні техногенного забруднення, супроводжується суттєвими змінами показників клінічного і фізіологічного стану організму тварин. У той же час отримані дані вказують на те, що тварини, які піддаються хронічному техногенному впливу через дію аліментарних і аерогенних чинників можуть адаптуватись до нових екологічних умов за рахунок процесів гомеостазу i, таким чином, зберігають клінічний і фізіологічний стан у межах допустимих відхилень, що супроводжується змінами інтенсивності процесів обміну речовин в організмі та рівня продуктивності.

Перспективи досліджень. Буде проводитись моніторинг результативності заходів 3 оздоровлення середовища від техногенних забруднювачів. 


\title{
PHYSIOLOGICAL AND FUNCTIONAL CHARACTERISTICS OF AN ORGANISM FATTENING CALVES FOR THE IMPACT OF ANTHROPOGENIC IMPACT
}

\author{
V. O. Velychko
}

State Scientific-Research Control Institute of Veterinary Medicinal and Feed Additives, 11, Donetska str., Lviv, 79019, Ukraine

\section{S U M M A R Y}

One of the topical problems for animal husbandry, in particular in areas of industrial pollution, is the development of scientific and practical bases for its management. The technological burden on the environment and contamination of agricultural lands by different xenobiotics is manifested by the immunodeficiency state of the organism of animals, and can also cause mutagenic, teratogenic, even embryotoxic effects. The main environmental factors are the main causes that significantly affect the functional state of the organism, the health of animals, and, accordingly, people. Particularly acute, this problem is felt in areas where industrial emissions are not controlled, mineral fertilizers, herbicides, pesticides, and means of stimulating the development of plants are introduced unsystematically. Studies have confirmed that in these areas, the content of heavy metals in soil, water, and, respectively, feeds used in livestock, which reduces their biological and nutritional value and contributes to the accumulation of toxic compounds in the body increases. Therefore, it is worth noting the need to improve, in the areas of anthropogenic impact, agricultural production in general, as well as systems for livestock farming and animal feeding in particular. A justifiable direction in this work would be to monitor xenobiotics, in particular heavy metals in the trophic chain: soil-plantfeed-animal-man.

The importance of obtaining such data is also due to the fact that with the change in the intensity of metabolic processes in the organism of productive animals in zones of anthropogenic impact it is possible to adjust the various processes of transformation of feed components and their transformation into products, the speed and direction of the course of enzymatic reactions, and, thus, to normalize individual levels of metabolism, which, accordingly, will increase the productive qualities of animals and obtain quality and safe products. The question of the consequences of anthropogenic stress on the physiological and functional state of an organism of animals requires the expansion of appropriate research and development of measures for preserving the ecological balance of the environment and the preservation of animal welfare.

Keywords: TECHNOLOGICAL BURDEN, XENOBIOTICS, HARD METALS, METABOLISM, ENVIRONMENTAL EQUILIBRIUM, WELFARE OF ANIMALS..

\section{ФИЗИОЛОГО-ФУНКЦИОНАЛЬНАЯ ХАРАКТЕРИСТИКА ОРГАНИЗМА ОТКОРМОЧНЫХ БЫЧКОВ ПРИ ВОЗДЕЙСТВИИ ТЕХНОГЕННОЙ НАГРУЗКИ}

\author{
В. А. Величко
}
Государственный научно-исследовательский контрольный институт ветеринарных препаратов и кормовых добавок ул. Донецкая, 11, г. Львов, 79019, Украина

\section{А Н Н О Т А ЦИ Я}

Одной из актуальных проблем для животноводства, в частности в зонах техногенного загрязнения, есть разработка научно-практических основ его ведения. Техногенная нагрузка на среду и загрязнения сельхозугодий разными ксенобиотиками проявляется 
иммунодефицитным состоянием организма животных, а также может провоцировать мутагенное, тератогенное и даже эмбриотоксическое действие. К главным причинам, которые существенно влияют на функциональное состояние организма, здоровье животных, соответственно и людей относят экологическое состояние среды. Особенно острой эта проблема проявляется в районах, где не контролируются промышленные выбросы, бессистемно вносятся минеральные удобрения, гербициды, пестициды, средства, стимулирующие развитие растений. Исследованиями подтверждено, что в районах техногенного загрязнения повышается и содержание тяжёлых металлов в почве, воде, соответственно и кормах, которые используются животными, что снижает биологическую и питательную их ценность и способствует накоплению в организме токсических соединений. Исходя из этого, заслуживает внимания необходимость совершенствования, в зонах техногенной нагрузки, сельхозпроизводства в целом, системы ведения отрасли животноводства и кормления животных в частности.

Оправданным направлением в этой роботе является проведение мониторинга ксенобиотиков, в частности тяжёлых металлов в цепи: почва-растение-корм-животноечеловек. Важность получения именно таких данных вызвана ещё и тем, что с изменением интенсивности процессов метаболизма в организме продуктивных животных в зонах техногенной нагрузки можно целенаправленно коррегировать разными биологическиактивными добавками процессы превращения компонентов корма и трансформации их в продукцию, скорость и направление течения ферментативных реакций, и, таким образом, нормализовать отдельные звенья обмена веществ, что, соответственно будет способствовать повышению продуктивных качеств животных и получению качественной и безопасной продукции. Последствия техногенной нагрузки на физиолого-функциональное состояние организма животных нацеливают на расширение соответствующих исследований и разработки мероприятий по обеспечению экологического равновесия окружающей среды и сохранению благополучия животноводства.

Ключевые слова: ТЕХНОГЕННАЯ НАГРУЗКА, КСЕНОБИОТИКИ, ТЯЖЁЛЫЕ МЕТАЛЛЫ, МЕТАБОЛИЗМ, ЭКОЛОГИЧЕСКОЕ РАВНОВЕСИЕ, БЛАГОПОЛУЧИЕ ЖИВОТНОВОДСТВА.

\section{Л I T Е P A T У P A}

1. Величко В. О. Фізіологічний стан організму тварин, біологічна цінність молока і яловичини та їх корекція за різних екологічних умов середовища / В. О. Величко // Монографія: Львів: Кварт, 2007. - 294 с.

2. Пилипів I. I. Джерела забруднення довкілля окремими важкими металами та їх вплив на життєздатність організму тварин / I. I. Пилипів, Р. С. Федорук // НТБ інституту біології тварин. - 2000. - Вип. 2. - С. 26-32.

3. Рівіс Й. Ф. Обмінні процеси в печінці жуйних тварин з різних екологічних зон / Й. Ф. Рівіс, Р. С. Федорук, В. О. Величко // Матер. наук.-прак. семінару-симпозіуму.Кузнецовськ-Львів. - 1995.- С. 28-31.

4. Федорук Р. С. Фізіолого-біохімічний статус організму корів в умовах екологічного забруднення довкілля / Р. С. Федорук, В. В. Гуменюк, Г. В. Колісник // НТБ ІЗБТ, - Львів, 1999, - Вип. 1(3). - С. 282-285.

5. Мікроелементний склад кормів і їх використання в організмі молодняка ВРХ в різних екологічних зонах/ В. О. Величко, М. В. Луз, І. М. Фостик та ін. // Матер. наук.-прак. семінарусимпозіуму. - Кузнецовськ-Львів. - 1995. - С. 22-25. 


\title{
References
}

1. Velychko V. O. Fiziolohichnyy stan orhanizmu tvaryn, biolohichna tsinnist' moloka i yalovychyny ta yikh korektsiya za riznykh ekolohichnykh umov seredovyshcha. Monohrafiya: / V. O. Velychko // L'viv: Kvart, 2007. - 294 s.

2. Pylypiv I. I., Fedoruk R. S. Dzherela zabrudnennya dovkillya okremymy vazhkymy metalamy ta yikh vplyv na zhyttyezdatnist' orhanizmu tvaryn // NTB instytut biolohiyi tvaryn.2000.-Vyp. 2.- S. 26-32.

3. Rivis Y. F., Fedoruk R. S., Velychko V. O. Obminni protsesy v pechintsi zhuynykh tvaryn z riznykh ekolohichnykh zon // Materialy nauk.-prakt. seminaru-simpoziumu. - Kuznetsovs'k L'viv. - 1995.- S. 28-31.

4. Fedoruk R. S., Humenyuk V. V., Kolisnyk H. V. Fizioloho-biokhimichnyy status orhanizmu koriv v umovakh ekolohichnoho zabrudnennya dovkillya // NTB IZBT, — L'viv, 1999, — Vyp. 1(3).-S. 282-285.

5. Mikroelementnyy sklad kormiv i yikh vykorystannya v orhanizmi molodnyaka VRKH v riznykh ekolohichnykh zonakh/ V. O. Velychko, M. V. Luz, I. M. Fostyk ta in. // Materialy nauk.prakt. seminaru-simpoziumu.- Kuznetsovs'k-L'viv. - 1995.- S. 22-25.

Рецензент — Р. С. Федорук, д. вет. н., професор, членкор НААН, Інститут біології тварин НААН.

УДК 619:612.821:612.128:636.2

doi: $10.36359 /$ scivp.2019-20-2.02

\section{ВМІСТ ЛІТІЮ В КРОВІ КОРІВ ІЗ РІЗНИМ ВЕГЕТАТИВНИМ СТАТУСОМ, ЗАЛЕЖНО ВІД ПОРИ РОКУ}

\author{
О. В. Журенко, канд. вет. наук, дочент, \\ B. I. Карповський, д-р вет. наук, професор, \\ О. В. Данчук, д-р вет. наук, дочент
}

Національний університет біоресурсів і природокористування України вул. Героїв Оборони, 15, м. Київ-41, 03041, Україна

Наведено результати досліджень впливу тонусу автономної нервової системи на вміст Літію в крові корів, залежно від пори року. Вміст металу в сироватиі, ціільній крові та клітинах крові корів, залежно від їх вегетативного статусу та пори року, становить, відповідно, 0,42-0,51 мкг/100 мл, 0,34-0,41 мкг/100 мл та 0,17-1,22 мкг/100 мл. Встановлено, що пора року чинить достовірний вплив лише на вміст Літію в сироватиі та цільній крові корів, у яких переважає тонус симпатичного відділу автономної нервової системи. Встановлено залежність вмісту Літію у крові корів від тонусу автономної нервової системи. Переважання впливу на роботу серия парасимпатичного відділу автономної нервової системи, незалежно від пори року, не чинить вплив на вміст Літію в сироватці, ијільій крові та ї̈ клітинах. Переважання впливу на роботу серия симпатичного відділу автономної нервової системи влітку чинить достовірний вплив лише на вміст Літію в клітинах крові $\eta_{\chi}^{2}=0,58(p<0,05)$, тодi, як взимку цей вплив стає сильнішим - $\eta_{\chi}^{2}=0,73(p<0,01)$. Так, 